\title{
NOSITELÉ NOBELOVY CENY ZA EKONOMII PRO ROK 2020
}

\section{Pavel Sirůček ${ }^{a}$, Lada Rusmichováa}

Američané Paul Robert Milgrom (*1948) a Robert Butler Wilson (*1937), oba ze Stanfordovy univerzity, získali pro rok 2020. Nobelovu cenu za ekonomii (The Sveriges Riksbank Prize in Economic Sciences in Memory of Alfred Nobel). Ocenění bylo uděleno za ,vylepšení teorie aukci a objevy nových formátů aukci“. Podle oficiálního zdůvodnění jmenovaní objasnili fungování aukcí a na základě svých teoretických objevů formulovali nové podoby aukcí pro komodity a služby, které je obtížné prodat tradičním způsobem (např. radiofrekvence). Zdůrazňováno je, že titíž autoři průkopnicky rozvinuli teorii i praktické aplikace se širokými dopady.

Jména Milgroma i Wilsona náležela při tipování budoucích nositelů (na základě citovanosti či respektu vědecké obce) již řadu let k nejskloňovanějším, takže rozhodnutí překvapivé není. Celkový počet ekonomických laureátů dosáhl od roku 1969 čísla 86 a opětovně umocnil drtivou dominanci Američanů. Americká př́íslušnost je uváděna (resp. spoluuváděna) u šedesáti pěti vyznamenaných. K tomu i mnozí z neamerických držitelů působí na univerzitách v USA. Ocenění za rok 2020 je v pořadí páté pro ekonomy, kteří v době udělení uvádějí jako působiště Stanfordovu univerzitu. Žebríčku vévodí Chicagská univerzita s třinácti cenami.

Experti na teorii her Milgrom a Wilson významně přispěli k rozvoji aukčních mechanismů. Na teoretické základy postavili aukce elektromagnetického spektra nebo míst pro těžbu a dražby v dalších sférách. Objasnili chování účastníků např. při současných prodejích více položek, stanovili pravidla pro vstup, průběh, způsob interakcí či volbu vítěze a analyzovali dopady aukcí na ekonomiku a celou společnost. Volba mechanismu a nastavení aukce silně ovlivňuje výsledek, nebot' aktéři jednají strategicky s využitím dostupných informací. Přitom účastníci aukcí zohledňují též své domněnky o znalostech ostatních dražitelů. Nové formáty použité u aukcí rádiových frekvencí, energií, kvót na lovení ryb či emisních povolenek vedle výnosů neopomíjí širší společenský prospěch. U komplexních aukcí si nelze již vystačit s principem, že vyhrává nejvyšší nabídka. Například u aukcí

a Vysoká škola ekonomická v Praze, Fakulta podnikohospodářská

E-mail: pavel.sirucek@vse.cz,rusmichl@vse.cz 
elektřiny je důležitá také spolehlivost dodávek. Aukce internetové reklamy berou kromě nabízené ceny v potaz relevanci reklamy pro uživatele. Při dražení kmitočtů pro mobilní telefony je důležité vybudování a následné provozování sítě za přijatelné ceny. Milgrom (2012) kritizoval výběr dalších mobilních operátorů v ČR při aukci frekvencí pro mobilní sítě 4G. Systém, nastavený Českým telekomunikačním úřadem, označil za nešt’astný. Souběžně se dražily všechny frekvence, byly známé př́hozy konkurentů a bylo možné vzít zpět nejvyšší nabídku. Aukce byla v roce 2013 zrušena pro nevhodné podmínky, které aukci protahovaly, a kvůli vysoké ceně, která měla mít za následek drahá mobilní data.

Milgrom navazuje na W. S. Vickreye, považovaného za zakladatele teorie aukcí, a na studie Wilsona. Vickrey se zabýval asymetrií informací např. při provádění aukcí, kdy na aukce aplikoval teorii her (1961). Analyzoval charakteristiky (chování účastníků, dosažené ceny apod.) různých typů aukcí a hledal způsob, jak aukce strukturovat tak, aby vedly k efektivním výsledkům. Poukázal na potenciální neefektivnost dobově tradiční metody aukce s nabídkami $\mathrm{v}$ zalepených obálkách. Tato přitom může vést $\mathrm{k}$ neefektivním výsledkům, nebot' rozhodování účastníků může být deformováno snahou brát do úvahy i nabídky ostatních. Pro řešení deformací doporučil metodu tzv. druhé nejlepší obálky, kdy dokazoval nezmanipulovatelnost druhé ceny (vickreyovská aukce). Metoda se rozšířila při prodejích vládních cenných papírů v USA, vypisování tendrů na veřejné projekty, vydražování vysílacího spektra aj.

Wilsonovy studie racionality ukazují, že zájemci o koupi mívají tendenci předkládat nabídky, které jsou pod jejich nejvy̌šsí odhadní cenou. Obávají se fenoménu „prokletí vítěze", tedy že zaplatí př́iliš a nakonec skončí ve ztrátě kvůli přehnaně optimistickému vyhodnocení budoucích výnosů. $\mathrm{K}$ dalším problémům může docházet při asymetrii informací účastníků či tehdy, pokud vítěz aukce má velkou vyjednávací sílu a nakonec si prosadí změnu podmínek (a stát jej vlastně ochrání před dopady vlastního rozhodnutí). Milgromova teorie aukcí kalkuluje nejenom s obecnou, nýbrž i soukromou hodnotou, která se u jednotlivých kupujících liší. Milgrom s Wilsonem a dalšími zkonstruovali mechanismus simultánních vícekolových aukcí s omezením prostoru pro manipulace. Použit byl poprvé roku 1994, kdy se frekvenční pásma v USA dražila současně. Předtím byla rozdělována spíše náhodně pomocí licencí (udělovaných na principu „soutěží krásy”) a loterijním losováním, což např. vedlo ke geografickému rozkouskování sítí. Rozmach mobilní komunikace umocnil problémy s lobbingem, korupcí a spekulacemi s licencemi. Průlomem se staly aukce kmitočtů mobilních sítí, přinášející prospěch kupujícím, prodávajícím i daňovým poplatníkům. V 21. století Milgromův tým navrhl design dvojitých pobídkových aukcí při hledání moderních využití televizního vysílacího spektra v USA.

U ekonomických výzkumů oceněných za rok 2020 bývá vyzdvihováno př́močaré propojení teorie s úspěšným praktickým využitím. Milgrom a Wilson navrhli nové, 
optimalizované podoby aukcí, které se v praxi úspěšně využívají. Jejich obsáhlý vědeckovýzkumný záběr přitom oživuje vzpomínky na velké ekonomické osobnosti oceněné ve 20. století. Čímž se liší od laureátů (a laureátek) z let nedávných, kdy některá jména byla překvapivá i relativně neznámá a šlo o úžeji profilované specialisty. Na straně druhé si ale lze položit otázku, zda teorie a praxe aukcí je opravdu tou nejpalčivější výzvou, které ekonomická věda v současnosti čelí ve světle bubliny 4.0 a její zelené etapy, robotizace, demografických posunů či hrozeb stagnací a krizí spojených nejenom s pandemií. Nezbytné je však připomenutí, že ekonomické nobelovské ocenění přichází se zpožděním a objevy musí obstát ve zkoušce časem.

\section{Teoretik a praktik širokého záběru Paul Robert Milgrom}

P. R. Milgrom se narodil 20. 4. 1948 v Detroitu. Vzdělával se na Michiganské univerzitě (AB v matematice - 1970). Pracoval jako pojistný matematik v San Franciscu a Columbusu. Od roku 1975 studoval na Stanfordské univerzitě (MS ve statistice - 1978, Ph.D. v podnikání - 1979). Jeho disertace, pod vedením R. B. Wilsona, nesla název The Structure of Information in Competitive Bidding (1979). Jako docent a profesor ekonomie vyučoval na Northwestern University (1979-1983), byl profesorem managementu na Yaleově univerzitěě (1983-1987) a od roku 1987 působí na Stanfordské univerzitě. Zastával post profesora ekonomie (1987-1993) či vedoucího Stanford Institute for Theoretical Economics (1989-1991), od roku 1993 je profesorem humanitních věd.

Působí ve významných časopisech, je členem National Academy of Sciences, American Academy of Arts and Sciences, American Economic Association, Econometric Society atd. Získal řadu ocenění za průkopnické teoretické př́spěvky (týkající se informací, pobídek, smluv, aukcí, tržního designu, organizace trhů a odvětví, financí, teorie her) a jejich aplikace. Nobelovskou přednášku pronesl již v roce 1996, a to za W. S. Vickreye, který se jí nedožil. Svou přednášku při přebírání Nobelovy ceny proslovil 7. 12. 2020 na téma Auction Theory Evolving: Theorems and Applications.

Jako přední světový návrhář aukcí poskytoval poradenské služby regulačním orgánům v USA, Velké Británii, Kanadě, Austrálii, Německu, Švédsku, Mexiku a firmám Microsoft, Google aj. týkající se aukcí rádiového spektra či reklam ve vyhledávání. Je spoluzakladatelem několika společností jako Milgrom, resp. Auctionomics, které se zabývají projektováním a realizací aukcí, sofwarovými službami pro obchodování a pomáhají při burzách a dražbách. Využívají moderní technologie, včetně např. počítačových simulací strategií přihazování s důrazem nejenom na emoce (které jsou důležité při aukcích jichž se zúčastňují spotřebitelé), ale především na rozpočty a byznysové plány dražitelů při zohlednění specifik dané aukce. 
Šíre Milgromova odborného zájmu zasahuje do mnoha sfér mikroekonomické teorie s přesahy do makroekonomie. Publikuje s laureáty Nobelovy ceny (R. B. Wilson, A. E. Roth, B. R. Holmström, D. C. North) a spolupracuje s dalšími osobnostmi (N. L. Stokeyová, D. M. Kreps). Vedle rozpracování teorie aukcí, včetně formulace principu propojení (1982a, 2004), prrispívá k rozvoji teorii her a matematické ekonomie - problematiky reputace (1982d), distribučních strategií (1985), opakovaných her (1991a), supermodulárních her (1990a,b), učení se ve hrách či monotónnosti (1994a, 2002). Obohacuje filozofii teoretického modelování v ekonomi studiemi komparativní statiky (1994b aj.) anebo úvahami o předpokladech modelů (1990b).

Podílí se na aplikacích teorie her a ekonomie informací do sféry aukcí, cen, organizací, kontraktů a finančních trhů. Formuluje nové techniky zkoumání motivací a pobídek v teorii agentů (1987a, 1991b, 1994c), řeší odhalování informací, rozpracovává teorii organizací (1990b aj.), včetně lobbování. Rozvíjí př́istupy nedokonalých a asymetrických informací ohledně limitních cen nebo reklamy (1986). Zkoumá postupy oligopolních hráčů, včetně předpokladů, za kterých je pro firmy racionální vydávat prostředky na reklamu či stanovovat ceny na úrovni ztráty, aby bylo zamezeno prŕíchodu konkurentů. Instrumenty teorie her aplikuje do práva, na vývoj institucí i do hospodářských dějin (1990c). Zkoumá nedokonalosti trhů práce (1987b, 2008), dále burzy a finanční trhy, zejména v kontextu spekulativního obchodování a mikrostruktur trhu. Hledá odpovědi na otázky, proč se obchoduje s cennými papíry a zda lze těžit ze spekulací. Je spoluautorem věty o neobchodování (1982b), analyzující rovnováhu a efektivnost. Na základě učebnice (1992) koncipoval kurz Moderní firma v teorii a praxi, později spolupracoval na výuce prvního postgraduálního kurzu Market Design.

\section{Hlavní knižní publikace:}

The Structure of Information in Competitive Bidding (Garland Press, 1979a); Economics, Organization and Management (Prentice Hall, 1992 - spolu s. J. Robertsem); Putting Auction Theory to Work (Cambridge University Press, 2004).

\section{Klíčové stati a časopisecké příspěvky:}

A Convergence Theorem for Competitive Bidding with Differential Information (Econometrica, May 1979b); A Theory of Auctions and Competitive Bidding (Econometrica, September 1982a - spolu s R. J. Weberem); Information, Trade and Common Knowledge (Journal of Economic Theory, February 1982b - spoluautorka N. L. Stokeyová); Pricing and Entry under Complete Information: An Equilibrium Analysis (Econometrica, March 1982c - spolu s J. Robertsem); Rational Cooperation in the Finitely Repeated Prisoners' Dilemma (Journal of Economic Theory, August 1982d -spoluautoři D. M. Kreps, 
R. B. Wilson, J. Roberts); Distributional Strategies for Games with Incomplete Information (Mathematics of Operations Research, November 1985 - spolu s R. J. Weberem); Price and Advertising Signals of Product Quality (Journal of Political Economy, August 1986 - spolu s J. Robertsem); Aggregation and Linearity in the Provision of Intertemporal Incentives (Econometrica, March 1987a - spoluautor B. R. Holmström); Job Discrimination, Market Forces and the Invisibility Hypothesis (Quarterly Journal of Economics, August 1987b - spoluautorka S. M. Osterová); Rationalizability, Learning and Equilibrium in Games With Strategic Complementarities (Econometrica, November 1990a spolu s J. Robertsem); The Economics of Modern Manufacturing: Technology, Strategy and Organization (American Economic Review, June 1990b - spolu s J. Robertsem); The Role of Institutions in the Revival of Trade: The Law Merchant, Private Judges, and the Champagne Fairs (Economics and Politics, March 1990c - spoluautoři D. C. North, B. R. Weingast); Information and Timing in Repeated Partnerships (Econometrica, November 1991a - spoluautoři D. Abreu, D. Pearce); Multitask Principal-Agent Analyses: Incentive Contracts, Asset Ownership and Job Design (Journal of Law, Economics, \& Organization, January 1991b - spolu B. R. Holmströmem); Monotone Comparative Statics (Econometrica, January 1994a - spolu s Ch. Shannonovou); Comparing Equilibria (American Economic Review, June 1994b - spoluautor J. Roberts); The Firm as an Incentive System (American Economic Review, September 1994c - spolu s B. R. Holmströmem); Envelope Theorems for Arbitrary Choice Sets (Econometrica, March 2002 - spolu s I. R. Segalem); The Limited Influence of Unemployment on the Wage Bargain (American Economic Review, September 2008 - spolu s R. E. Hallem); Designing Random Allocation Mechanisms: Theory and Applications (American Economic Review, April 2013 - spoluautoři E. Budish, Y. K. Che, F. Kojima); Equilibrium Selection in Auctions and High Stakes Games (Econometrica, January 2018 - spoluautor J. Mollner); Clock Auctions and Radio Spectrum Reallocation (Journal of Political Economy, January 2020 - spolu s I. R. Segalem).

\section{Doplňující informace:}

Counterspeculation, Auctions, and Competitive Sealed Tenders (Vickrey, W. S., Journal of Finance, March 1961); Industrial Structure in the New Industrial Economics (Bonanno, G., Brandolini, D. (eds.), Oxford University Press, 1990); Perspectives on Positive Political Economy (Alt, J. E., Shepsle, K. A. (eds.), Cambridge University Press, 1990); Contingent Valuation: A Critical Assessment (Hausman, J. (ed.), Elsevier-North Holland, 1993); Auction Theory (Krishna, V., Academic Press, 2002); Paul Milgrom: Aukce může ekonomice pomoci i uškodit, záleží, jak se nastaví pravidla (Hospodářské noviny, 16. 11. 2012); Market Design (Haeringer, G., MIT Press, 2018); https://milgrom.people.stanford.edu/; http://www.auctionomics.com/. 


\section{Odborník na teorie her a jejich aplikace Robert Butler Wilson}

R. B. Wilson, narozen 16. 5. 1937 v městě Geneva v Nebrasce, absolvoval Harvardově univerzitě (BA v matematice - 1959, MBA - 1961, DBA - 1963). Disertaci A Simplicial Algorithm for Concave Programming obhájil na Harvardově obchodní škole (1963). Práce představuje sekvenční kvadratické programování, které nalezlo uplatnění v rámci nelineárního programování. Vyučoval na Kalifornské univerzitě (1963-64) a od roku 1964 je spojen se Stanfordskou univerzitou. Na stanfordské Graduate School of Business zastával posty asistenta a docenta (1964-1971), resp. profesora (1971-1976). Následně byl profesorem ekonomie (1976-2000), profesorem managementu (2000-2004) a od roku 2004 je na Stanford Business School profesorem emeritním. K jeho doktorandům náleželi, vedle Milgroma, ,nobelisté “ A. E. Roth a B. R. Holmström nebo Y. Sannikov (laureát John Bates Clark Medal 2016).

Wilson hostoval na Katolické univerzitě v Lovani (1967), spolupracoval s Centre for Advanced Study in the Behavioral Sciences při Stanforské univerzitě (1977-1978) a Harvard Law School při Harvardově univerzitě (1993-2001). Působil jako znalec antimonopolního zákonodárství a cenných papírů. Poskytoval poradenství americkým či kanadským úřadům a společnostem ohledně cenových strategií (při stanovení cen elektřiny, cen v odvětvích high technology, při podávání nabídek, financování výzkumu atd.). Společně s Milgromem projektovali podobu řady aukcí energií, elektřiny, plynu a telekomunikací v USA. Jeho další návrhy aukcí a cenových schémat byly implementovány do veřejných služeb a využity i soukromými firmami v komunikačním, ropném či energetickém průmyslu.

Redakčně působil v prestižních časopisech, je členem National Academy of Sciences, American Academy of Arts and Sciences, American Economic Association, Econometric Society, Game Theory Society atd. Byl poctěn čestnými doktoráty, obdržel několik ocenění - např. Frontiers of Knowledge in Economics, BBVA Foundation (2016), společně s P. M. Milgromem a D. M. Krepsem získal cenu National Academy of Sciences 2018 John J. Carty Award for the Advancement of Sciences. Wilsonova tradiční přednáška při přebírání Nobelovy ceny 7. 12. 2020 nesla název Strategic Analysis of Auction Markets.

Zpočátku se zaměřoval na optimalizaci (disertace 1963, 1966) a teorii společenské volby (1969, 1972, 1975). Dále rozvíjí ekonomickou teorii $(1968,1978 a, b, c, 1988)$ a různé oblasti teorie her - její základy (1982a, b, c, 2012), aukce a dražby (1977, 1979, 1985a), vyjednávání (1998), modelování výběru (2014), výpočty (1971, 1992, 2009, 2010). Značnou pozornost věnuje projektování podob trhů a problematice cen (1985b, 1986, 1987, 1993, 2002).

Wilson staví na propojení ekonomické vědy s praktickým managementem, kdy ke zdrojům témat jeho teoretického zkoumání náleží hlavně investice a cenová tvorba. Jako 
matematický ekonom celoživotně pracuje na rekonstrukci ekonomické teorie na bázi teorie her. Usiluje o postižení dynamiky, načasování, strategičnosti rozhodování a informačních rozdílů. Věří, že výzkumy reálného vyjednávání osvětlují problémy lépe nežli akademická axiomatizace. Prostřednictvím teorie her rozvíjí modely společenské volby a blahobytu a nahlíží na hospodářské politiky. Přispívá k reformulaci organizace trhů a odvětví a teorie organizace pomocí instrumentaria nekooperativních her (2019 aj.). Řeší vyjednávání o mzdách či stávkách, analyzuje cenové války a predátorské ceny. Za průkopnické bývají považovány studie strategických interakcí v situaci nedokonalých a asymetrických informací. Se zdůrazněním významu jednoduchých strategií i při řešení složitých problémů. Dále proslul př́spěvky k managementu a podnikové ekonomice, jeho výzkumy nelineární cenové tvorby ovlivnily politiku firem např. v energetickém průmyslu, zejména u elektrické energie (1968, 1993, 2002). Encyklopedická kniha Nonlinear Pricing z roku 1993 analyzuje návrhy tarifů a souvisejících témat pro veřejné služby, včetně energetiky, komunikací a dopravy. Vlivným se stal text The Theory of Syndicates (1968), zabývající se rizikem, očekávaným užitkem a paretooptimalitou.

Nejen v souvislosti se složitým předivem struktur trhů produktů a výrobních faktorů (především práce) Wilson připomíná, že teorie nikdy nemůže postihnout bohatství praxe, ale měla by se pokusit reflektovat stěžejní rysy praxe. Za důležitou označuje již samotnou formulaci problému. Zdůrazňuje význam zkoumání cenových strategií, včetně diskriminačních postupů a cen za veřejné služby. Za významný aspekt výzkumu považuje zachycování dopadů pobídek a stimulů na efektivnost, a to v komerčních jednáních (aukce, vyjednávání, obchodování na finančních trzích s poptávkovou a nabídkovou cenou aj.), při zadávání zakázek nebo v organizaci firem.

\section{Hlavní knižní publikace:}

Nonlinear Pricing (Oxford University Press, 1993); Barriers to Conflict Resolution ((eds.), W. W. Norton, 1995 - spolueditoři K. J. Arrow, R. H. Mnookin, L. Ross, A. Tversky).

\section{Klíčové stati a časopisecké příspěvky:}

Computation of Optimal Controls (Journal of Mathematical Analysis and Applications, April 1966); The Theory of Syndicates (Econometrica, January 1968); An Axiomatic Model of Logrolling (American Economic Review, June 1969); Computing Equilibria of N-Person Games (SIAM Journal of Applied Mathematics, July 1971); Social Choice Theory without the Pareto Principle (Journal of Economic Theory, December 1972); On the Theory of Aggregation (Journal of Economic Theory, February 1975); A Bidding Model of Perfect Competition (Review of Economic Studies, October 1977); Competitive Exchange (Econometrica, May 1978a); Information, Efficiency and the Core 
of an Economy (Econometrica, July 1978b); The Bilinear Complementarity Problem and Competitive Equilibria of Piecewise Linear Economic Models (Econometrica, January 1978c); Auctions of Shares (Quarterly Journal of Economics, November 1979); Rational Cooperation in the Finitely Repeated Prisoners'Dilemma (Journal of Economic Theory, August 1982a - spoluautoři D. M. Kreps, P. M. Milgrom, J. Roberts); Reputation and Imperfect Information (Journal of Economic Theory, August 1982b - spolu s D. M. Krepsem); Sequential Equilibria (Econometrica, July 1982c - spolautor D. M. Kreps); Competitive Nonlinear Tariffs (Journal of Economic Theory, February 1983 - spolu s S. Orenem a S. Smithem); Incetive Efficiency of Double Auctions (Econometrica, September 1985a); Capacity Pricing (Econometrica, May 1985b - spoluautoři S. Oren, S. Smith); Multi-Level Demand-Subscription Pricing for Electric Power (Energy Economics, October 1986 spoluautoři H. Chao, S. Oren, S. Smith); Priority Service: Pricing, Investment and Market Organization (American Economic Review, December 1987 - spoluautor H. Chao); Credentials and Wage Discrimination (Scandinavian Journal of Economics, December 1988); Efficient and Competitive Rationing (Econometrica, January 1989); Computing Simply Stable Equilibria (Econometrica, September 1992); A Theory of Discovery in Litigation (Games and Economic Behavior, November 1998 - spoluautor R. H. Mnookin); Architecture of Power Markets (Econometrica, July 2002); Sufficient Conditions for Stable Equilibria (Theoretical Economics, June 2006 - spoluautor S. Govindan); Global Newton Method for Stochastic Games (Journal of Economic Theory, January 2009 - spolu s S. Govindanem); A Decomposition Algorithm for N-Players Games (Economic Theory, January 2010 - spoluautor S. Govindan); Axiomatic Theory of Equilibrium Selection for Generetic Two-Players Games (Econometrica, July 2012 - spolu s S. Govindanem); Competition for a Majority (Econometrica, January 2014 - spoluautoři P. Barelli, S. Govindan); How Market Design Emerged from Game Theory: A Mutual Interview (Journal of Economic Perspectives, Summer 2019 - spolu s A. E. Rothem).

\section{Doplňující informace:}

Mathematical Programming (Hu, T. C., Robinson, S. M. (eds.), Academic Press, 1973); Discounting for Time and Risk in Energy Policy (Lind, R. C. (ed.), John Hopkins University Press, 1982); Auctions, Bidding, and Contracting: Uses and Theory (EngelbrechtWiggans, R., Shubik, M., Stark, R. M. (eds.), New York University Press, 1983); Game Theoretic Models of Bagraining with Incomplete Information (Roth, A. E. (ed.), Cambridge University Press, 1985); Perspectives on Deterrence (Stern, P. C., Axelrod, R., Jervis, R., Radner, R. (eds.), Oxford University Press, 1989); The Economics of Imperfect Competition and Employment (Feiwel, G. R. (ed.), Macmillan, 1989); Handbook of Game Theory, Vol. 1 (Aumann, R. J., Hart, S. (eds.), North Holland, 1992); Design 
of Restructured Power Markets (Chao, H., Huntington, H. (eds.), Kluwer Academic Press, 1998); Game Theory and Business Applications (Chatterjee, K., Samuelson, W. (eds.), Kluwer Academic Press, 2001); The Economics of Public Utilities (Rees, R. (ed.), Edward Elgar, 2006); Competitive Electricity Markets: Design, Implementation, Performance (Sioshansi, F. P. (ed.), Elsevier, 2008); Handbook of Pricing Management (Ozer, O., Phillips, R. (eds.), Oxford University Press, 2012); The Handbook of Market Design (Vulkan, N., Roth, A. E., Neeman, Z. (eds.), Oxford University Press, 2013); https://gsbfaculty.stanford.edu/robert-wilson/ 